\title{
AN ASSESSMENT OF PAKISTANI PHARMACY AND MEDICAL STUDENTS' KNOWLEDGE OF BLACK BOX WARNINGS
}

\author{
G. Murtaza ${ }^{1}$, S.A. Khan ${ }^{1}$, G. Murtaza (Junior) ${ }^{1}$, K. Javed ${ }^{1}$, F. Akram¹ ${ }^{1}$ A.A. Hamid ${ }^{1}$, I. Hussain ${ }^{1}$
}

\begin{abstract}
Food and Drug Administration delivers the black box warnings (BBW) which should appear on the leaflets of medicines for patient awareness and the prescription of drugs indicating its highly fatal adverse effects to human body. The aim of this study was to assess the knowledge of Pakistani pharmacy and medical students about BBW. A questionnaire containing contents about BBW was given to the $1^{\text {st }}, 2^{\text {nd }}$ and $3^{\text {rd }}$ professional year pharmacy and medical students from different pharmacy and medical institutes. A $76 \%$ survey response rate was observed. It was observed that student's knowledge about BBW improves in association with the promotion in professional years of pharmacy and medical education. The results indicate that student's knowledge about black box increases with the study level. Training in black box warnings should be implemented in pharmacy and medical institutions influencing the meaningful ways to educate and train pharmacy and medical students, and help these students to get recent knowledge about black box warnings so that, in future, they may perform an ethical practice in their respective fields.
\end{abstract}

Key words: side effects, Food and Drug Administration, training, questionnaires based survey

\section{Una evaluación del conocimiento de estudiantes de medicina y de farmacia en Pakistán sobre alertas de medicamentos}

Resumen: La Agencia Reguladora de Alimentos y Medicamentos comunica alertas sobre medicamentos (AM), que debieran aparecer en los prospectos de medicinas, para el conocimiento de los pacientes y la prescripción de medicamentos, indicando sus efectos adversos fatales para el cuerpo humano. El objetivo de este estudio es averiguar el conocimiento de estudiantes de medicina y de farmacia sobre AM. Se entregó un cuestionario con contenidos sobre AM a estudiantes de farmacia y de medicina de primero a tercer año de diferentes institutos médicos y farmacéuticos. Se obtuvo un $76 \%$ de respuesta. Se observó que el conocimiento de los estudiantes sobre AM mejora asociado a la promoción en años profesionales de medicina y farmacia. Los resultados indican que el conocimiento de los estudiantes sobre alerta de medicamentos aumenta con el nivel de estudio. Debería implementarse la formación sobre alerta de medicamentos en farmacia y medicina y ayudar a los estudiantes a tener conocimiento actual sobre alerta de medicamentos de forma que, en el futuro, puedan realizar prácticas éticas en sus campos respectivos.

Palabras clave: efectos secundarios, Agencia Reguladora de Alimentos y Medicamentos, formación, cuestionarios basados en encuestas

\section{Uma avaliaçáo sobre o acesso de estudantes paquistaneses de medicina e farmácia ao conhecimento das advertências das caixas de tarja preta}

Resumo: A Food and Drug Administration disponibiliza as advertências das caixas de tarja preta (BBW) que devem aparecer em bulas de medicamentos para conscientização de pacientes e a prescrição de drogas, indicando seus efeitos adversos altamente fatais para o corpo humano. O propósito deste estudo foi o de de inteirar a cerca do conhecimento de estudantes de medicina e farmácia sobre BBW. Um questionário com conteúdos sobre BBW foi dado a estudantes de farmácia e medicina, do $1^{\circ}, 2^{\circ}$ e $3^{\circ}$ ano de diferentes instituiçóes de ensino em farmácia e medicina. Foi observada uma taxa de $76 \%$ de resposta dos pesquisados. Observou-se que o conhecimento de estudantes sobre BBW melhora quando se associa à promoção para anos seguintes da educaçáo nas faculdades de farmácia e medicina. Os resultados indicam que o conhecimento dos estudantes sobre as caixas de tarja preta aumenta com o nível de estudo. Treinamento com caixas de tarja preta pode ser implementado em instituiçóes de ensino de farmácia e medicina, influenciando de modo significativo as formas de educação e treinamento de estudantes de farmácia e medicina, e, assim, ajudar estes estudantes a obter conhecimentos recentes sobre medicamentos de tarja preta de modo que, no futuro, elas possam exercer uma prática ética em seus respectivos campos de atuação profissional.

Palavras-chave: efeitos colaterais, Food and Drug Administration, treinamento, pesquisa baseada em questionário

\footnotetext{
${ }^{1}$ Department of Pharmaceutical Sciences, COMSATS Institute of Information Technology, Abbottabad, Pakistan Correspondence: gmdogar356@gmail.com
} 


\section{Introduction}

Black box warnings (BBW) appear on the leaflets of medicines indicating its serious adverse effects for patient awareness(1). The BBW are delivered by FDA (Food and Drug Administration) for the prescription of drugs having highly fatal adverse effects to the body (2). The Adverse Event Reporting System and the Office of Surveillance and Epidemiology evaluate post-market safety observations and identify these safety concerns. The most widespread category of warning is released on observing a potentially severe unfavorable effect that must be vigilantly pondered against the potential advantage of the drug(3). The BBW are also released to attract attention to potential drug interactions, dosing and monitoring requisites. The BBW have recently been released for fluoroquinolones, oral sodium phosphate bowel preparations and salmeterol. Regardless of these extremely revealed BBW, all of these medications remain practical treatment choices with apposite patient assortment. Eventually, physicians must make a decision whether to prescribe drugs having boxed warnings(4-7). The BBW are imposed to the drugs which have been approved for marketing which include life threatening information(5).

Many black box warnings are collected by postmarketing surveillance, rather than controlled clinical trials(6). Newly approved drugs may exhibit more unrecognized adverse drug reactions as compared to the established drugs(7). The complete description, estimate risk and a conclusion of suspected effects by the harmful reactions and other risk factors like dose, sex, contraindications, age and duration of use is mentioned on the drugs leaflets having black box warnings. The pharmaceutical companies are required to reproduce black box warnings on the labeling or in the literature of the respective drugs. The informations about the restrictions of highly toxic drugs may also be included in the black box warnings. The total number of drugs having black box warnings is approximately $350(8-11)$. Due to the observations from other class members of the drug or because of the animal studies, the chances of an adverse reaction by a medicine can be expected $(9,13)$. Some black box warnings suggest against simultaneous administration of particular medicines attributable to an enlarged jeopardy for life-threatening effects.

In Pakistan, the black box was opened on January 1, 2005 and adopted FDA rules of black box warnings in Pakistan. The products in black box are processed under the developed rules(14). Healthcare providers like pharmacists are often not well-informed about the source, significance, and insinuations of these black box warnings. In this context, present study was designed to assess the knowledge of black box warnings among pharmacy and medical students of six institutes in Pakistan.

\section{Methodology}

Study design: The investigation about black box warnings among pharmacy and medical students was completed through cross-sectional study design. The basic purpose behind is survey is to establish knowledge among pharmacy and medical students and to check their current knowledge regarding to black box warnings. Data were assembled by questionnaires and through face-to-face interview. The survey was assessed by the combined efforts of faculty members and students of COMSATS Institute of Information Technology, Abbottabad. This study was approved by the Board of Advanced Studies and Research (Local Ethical Committee), COMSATS Institute of Information Technology, Abbottabad, Pakistan.

Study location: Six institutes in Pakistan [CIIT (COMSATS Institute of Information Technology), Hazara University (HU), PIPS (Pakistan Institute of Professional Studies), WIL (Women Institute of Learning) AMC (Ayub Medical College) and FMC (Frontier Medical College) were selected as research-rigorous organizations. The survey was conducted from undergraduate pharmacy and medical students. A two stage random sampling methodology was employed. During stage 1 , students were selected through simple random sampling and stage 2 covered the assortment of students from other locations. The students were briefed the aim of study and then obtained sanction from the students to participate in this study. The filling of questionnaires was conducted in the presence of an expert researcher for assisting the respondents, if required. 
Data collection: This survey was conducted using a structured pre-channeled questionnaire containing 28 different closed-ended and open-ended questions. The questionnaire contained questions on demography and students' knowledge about BBW of various medications. The questions on selected brand and generic medications (having a wide range of indications) corresponded to various factors like: (vi) medications with and without advertisement about the addition of black box warnings or severe undesirable outcomes, (iv) over the counter and prescription-only medications, (ii) frequency of use in clinical practice, and (v) the period of marketing. Based on Cohen's Kappa points for inter-annotator, the responses to open-ended questions were reviewed by two experts, who classified the responses with mutual harmony as correct or incorrect. Five questions covered the general knowledge about black box warnings, while 23 questions were asked about drugs having black box warnings. Demographic informations consisted of age, sex and year of their studentship. The respondents were also permitted to add any additional information regarding their knowledge about BBW. After pilot-testing for content and design on 25 students, necessary modifications were made in the questionnaire. The students were not allowed to use any helping material and discussion among each other. A complete examination environment for 15-20 min was provided to the students so that their personal knowledge about black box warnings could be assessed(4).

Data analysis: Data was analyzed using SPSS version 13.0 with confidence interval of $95 \%$.

\section{Results and discussion}

Firstly, it was checked that either students know "what are black box warnings" in response we observed that mean percentage of $69 \%, 80 \%$ and $83 \%$ from $1^{\text {st }}, 2^{\text {nd }}$ and $3^{\text {rd }}$ professional year pharmacy and medical students responded positively. Then, the activity was further continued by asking different types of medicines with their BBW using multiple choice questions. About 76\% students answered positively.

Different medications with BBW and the response strength of 1st PYPS (professional year pharmacy students) are shown in Figure 1. The $1^{\text {st }}$ PYPS have least knowledge about medicines with BBW having nominal familiarity about some common medicine's BBW like paracetamol (8\%), diclofenac sodium (7\%), flagyl (7\%) and alprostadil (4\%), respectively.

The observed survey response rate was 76\% (4256 of 5600 students) with $1^{\text {st }}$ PYPS $=590$ (Number of respondent from $1^{\text {st }}$ PYPS) $/ 1095$ (Total number of $1^{\text {st }}$ PYPS $), 2^{\text {nd }}$ PYPS $=729 / 972,3^{\text {rd }}$ PYPS $=$ $361 / 400$ and $1^{\text {st }}$ PYMS (professional year medical students $)=297 / 718,2^{\text {nd }}$ PYMS $=268 / 567$ and $3^{\text {rd }}$ PYMS $=418 / 509$. The remaining students did not complete the questionnaires.

It was observed that the ability of pharmacy students to answer about BBW in a list of 23 medicines increased in association with curriculum/ professional year. Third PYPS have a significant knowledge about black box drugs than first professional year students. Pharmacy students who responded correctly about black box warnings were as: $1^{\text {st }} P Y P S=53.88 \%, 2^{\text {nd }} P Y P S=75.00 \%$ and $3^{\text {rd }}$ PYPS $\left.=88.03 \%\right)$. Black box warning content for alprostadil $\left(1^{\text {st }}\right.$ PYPS $=3 \%, 2^{\text {nd }}$ PYPS $=$ $1 \%)$, rosiglitazone $\left(1^{\text {st }}\right.$ PYPS $=1 \%, 2^{\text {nd }}$ PYPS $=$ $5 \%, 3^{\text {rd }}$ PYPS $\left.=30 \%\right)$ and stavudine $\left(1^{\text {st }}\right.$ PYPS $=$ $2 \%, 2^{\text {nd }}$ PYPS $=5 \%, 3^{\text {rd }}$ PYPS $\left.=30 \%\right)$ etc., were least known by the students however BBW content for paracetamol $\left(1^{\text {st }}\right.$ PYPS $=55 \%, 2^{\text {nd }} P Y P S=$ $88 \%, 3^{\text {rd }}$ PYPS $\left.=98 \%\right)$, metronidazole $\left(1^{\text {st }}\right.$ PYPS $=54 \%, 2^{\text {nd }}$ PYPS $=83 \%$, and $3^{\text {rd }}$ PYPS $\left.=95 \%\right)$ and oxytocin $\left(1^{\text {st }}\right.$ PYPS $=52 \%, 2^{\text {nd }} P Y P S=48 \%$, and $3^{\text {rd }}$ PYPS $=98 \%$ ) were also known by the students as good as given in above data.

Table 1: Results obtained from the medical and pharmacy students about black box warnings

\begin{tabular}{|l|l|l|l|}
\hline & $\begin{array}{l}1^{\text {st }} \\
\text { Professional } \\
\text { Year }\end{array}$ & $\begin{array}{l}2^{\text {nd }} \\
\text { Professional } \\
\text { Year }\end{array}$ & $\begin{array}{l}3^{\text {rd }} \\
\text { Professional } \\
\text { Year }\end{array}$ \\
\hline Medical & $41.36 \%$ & $46.52 \%$ & $82.82 \%$ \\
\hline Pharmacy & $53.88 \%$ & $75 \%$ & $88.03 \%$ \\
\hline
\end{tabular}

Different medications and the responses from the $3^{\text {rd }}$ PYPS are shown in Figure 1. Knowledge of $2^{\text {nd }}$ PYPS about black box medication was quite better than $1^{\text {st }}$ PYPS. The whole percentage of 
$2^{\text {nd }}$ PYPS was $76 \%$ regarding the knowledge of black box medications. More then $90 \%$ knowledge of $2^{\text {nd }}$ PYPS was familiar about BBW of paracetamol, flagyl, diclofenac sodium and oxytocin. The least knowledge of $2^{\text {nd }}$ PYPS about BBW was about amoxapine $(30 \%)$, adefovir dipivoxil $(15 \%)$, cisplastin (14\%), lefnonoide (15\%) and hydoxyurea $(21 \%)$, respectively.

Different medications and the responses from the $2^{\text {nd }}$ PYPS are shown in Figure 1. In this survey, the most correct results were observed by $3^{\text {rd }}$ PYPS. They possessed knowledge of majority of the medicines with BBW. The $84 \%$ of $3^{\text {rd }}$ PYPS correctly answered about captopril, estradiol, flagyl, oxytocin and paracetamol as medicines having BBW. The $3^{\text {rd }}$ PYPS (50\%) had least knowledge about the BBW for amphetamine, ganeiclovir $(\mathrm{Na})$, leflunonoide and hydoxyurea.

Figure 1: The percentage of $1^{\text {st }}, 2^{\text {nd }}$ and $3^{\text {rd }}$ professional year pharmacy student's (PYPS) and $1^{\text {st }}, 2^{\text {nd }}$ and $3^{\text {rd }}$ professional year medical student's (PYMS) knowledge about 11 black box medications.

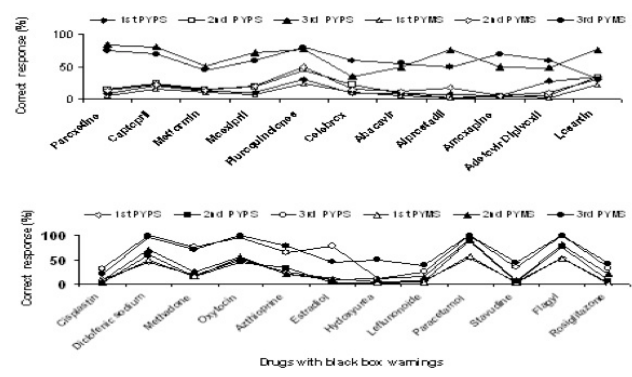

Figure 1 exhibit medical students' knowledge about BBW of medicines showing an increase in their knowledge with the seniority of professional year like pharmacy students. Like pharmacy students, some common medications with BBW were much known to 1st PYMS students i.e. paracetamol, diclofenac sodium, metronidazole and oxytocin.

Medical students who responded correctly about black box warnings were as: $1^{\text {st }}$ PYMS $=41.36 \%$, $2^{\text {nd }}$ PYMS $=46.52 \%$ and $3^{\text {rd }}$ PYMS $\left.=82.82 \%\right)$. Table 1 shows that 1st PYMS (professional year medical students) possess significantly $(\mathrm{p}<0.05)$ lesser knowledge as compared to that of 1 st professional year pharmacy students perhaps it is be- cause of that pharmacy students' interaction with pharmacology discipline is more than that of medical students. Same result was also seen in 2 nd and $3^{\text {rd }}$ PYMS.

Figure 2: Percentage of students from different institutions possessing good knowledge about black box warnings.

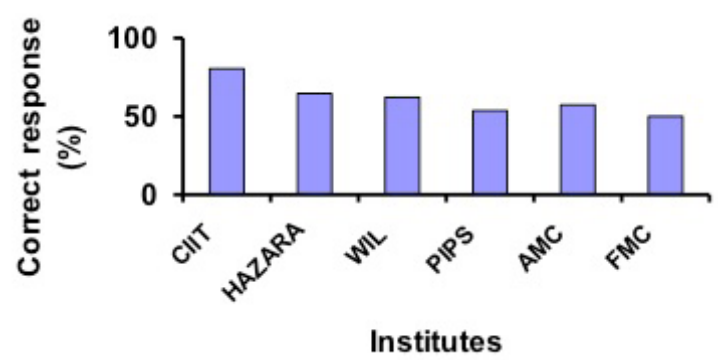

Figure 2 indicates that the number of students possessing sufficiently good knowledge about BBW from CIIT, HU, WIL, AMC, PIPS and FMC are 739/920 (80.32\%), 451/704 (64.06\%), $300 / 472 \quad(61.86 \%), \quad 676 / 1178 \quad(57.38 \%)$, $198 / 371(53.36 \%)$ and $307 / 611$ (50.20\%), respectively. Among the six institutions, the students of CIIT showed significantly $(\mathrm{p}<0.05)$ better knowledge about BBW, as black box warnings are not potentially taught in the other five institutions, it may be due to the lack of highly qualified faculty and less frequency of seminars, worshops and conferences in those five institutes.

The knowledge of black box warnings among pharmacy and medical students improves as the educational year progresses(5). Before survey, it was expected that the knowledge of students about black box warnings will be significantly less, as in Pakistan, pharmacy education and its practice is not as mature as in developed countries but the results were highly impressive when we observed the data obtained as a result of this survey.

The $1^{\text {st }}$ professional year students response about BBW was not satisfactory as their knowledge was very less because they do not study about drugs in their first year course plan. While $2^{\text {nd }}$ and $3^{\text {rd }}$ professional year students' response rate was impressive. Some common drugs having BBW were much known to many of the students of $1^{\text {st }}$ pro- 
fessional year like paracetamol and metronidazole but they could not justify their answers logically. On contrary, $2^{\text {nd }}$ professional year students' response to drugs like paracetamol, flagyl, oxytocin, estradiol and captopril was very effective as most of the $2^{\text {nd }}$ professional year students knew about exact reason of BBW for above mentioned drugs. The $3^{\text {rd }}$ professional year students, the most senior students of our survey responded very well like $2^{\text {nd }}$ professional year students, as their response was reasonably correct for BBW of majority of the drugs. Some drugs like paroxetine, methadone, oxytocin, paracetamol, metronidazole, diclofenac acid, alprostadil and losartin were much known to them.

A previous study elaborated that a large number of pharmacy students mentioned here do not stay updated with the latest issues of black box warnings. However, provision of data to the pharmacists and medical prescribes does not influence their behavior of prescription(12). There are many sources for informations regarding BBW like FDA website(7). At present, the study of BBW may be conducted under the umbrella theme of medication safety in the pharmacy and medical institutes, accompanied by a proper training to the students in this crucial area.

\section{Limitations of study}

Further studies are required for the identification of the students' knowledge about black box warnings. This survey was conducted only at six institutions which was a limitation of this study. The inclusion of other institutions in such study may produce different results as a result of an extensive survey. Awareness among the pharmacists and medical practioners about black box warnings should also be determined. Another limitation is that this survey instrument was not validated.

\section{Conclusion}

This survey about black box warnings conducted in $1^{\text {st }}, 2^{\text {nd }}$ and $3^{\text {rd }}$ professional year pharmacy and medical students shows that student's understanding and awareness of black box warnings improves with their professional year advancement. Training in black box warnings should be implemented in pharmacy and medical institutions influencing the meaningful ways to educate and train pharmacy and medical students, and help these students to get recent knowledge about black box warnings so that, in future, they may perform an ethical practice in their respective fields. 
An Assessment of Pakistani Pharmacy and Medical Students' Knowledge of Black Box Warnings - Ghulam Murtaza et al.

\section{References}

1. U.S. Food and Drug Administration. Guidance for industry. Warnings and precautions, contraindications, and boxed warning sections of labeling for human prescription drug and biological products — content and format.

2. Available at http://www.fda.gov/downloads/Drugs/Guidance ComplianceRegulatoryInformation/Guidances/ucm075096.pdf. Retrieved 2010-02-21.

3. Cohen A, Rabbani A, Shah N, Alexander GC. Changes in glitazone use among office-based physicians in the United States, 2003-2009. Diabetes care 2010; 33: 823-825.

4. Lasser KE, Allen PD, Woolhandler SJ, Himmelstein DU, Wolfe SM, Bor DH. Timing of new black box warnings and withdrawals for prescription medications. JAMA 2002; 287(17): 2215-2220.

5. Cook DM, Gurugubelli RK, Bero LA. Risk management policy and black-box warnings: a qualitative analysis of US FDA proceedings. Drug Saf 2009; 32(11): 1057-66.

6. Smalley W, Shatin D, Wysowski DK, et al. Contraindicated use of cisapride: impact of food and drug administration regulatory action. JAMA 2000; 284(23): 3036-3039.

7. Beach JE, Faich GA, Bormel FG, Sasinowski FJ. Black box warnings in prescription drug labeling: results of a survey of 206 drugs. Food Drug Law J 1998; 53(3): 403-411.

8. Wagner AK, Chan KA, Dashevsky I, et al. FDA drug prescribing warnings: is the black box half empty or half full? Pharmacoepidemiol Drug Safety 2006; 15: 369-386.

9. Lasser KE, Allen PD, Woolhandler SJ, Himmelstein DU, Wolfe SM, Bor DH. Timing of new black box warnings and withdrawals for prescription medications. JAMA 2002; 287(17): 2215-2220.

10. Dorsey R, Rabbani A, Gallagher SA, Conti R, Alexander GC. The impact of black box warnings on the use of atypical antipsychotic medicines. Arch Inter Med 2010; 170: 96-103

11. Weatherby LB, Nordstrom BL, Fife D, Walker AM. The impact of wording in "Dear doctor" letters and in black box labels. Clin Pharmacol Ther 2002; 72(6): 735-742.

12. Guo JJ, Curkendall S, Jones JK, Fife D, Goehring E, She D. Impact of cisapride label changes on codispensing of contraindicated medications. Pharmacoepidemiol Drug Safety 2003; 12(4): 295-303.

13. Cluxton RJ, Jr, Li Z, Heaton PC. Impact of regulatory labeling for troglitazone and rosiglitazone on hepatic enzyme monitoring compliance: findings from the state of Ohio medicaid program. Pharmacoepidemiol Drug Safety 2005; 14(1): 1-9

14. Rohra DK, Jawaid A, Rehman TU, Sukkurwala AQ, Palanpurwala AS, Gangwani R. black box warnings on the use of anti-anxiety medicines. Pak J Med Res 2007; 46: 351-356.

15. Strijbos J, Martens R, Prins F, Jochems W. New black box warnings. Comp Edu 2006; 46: 29-33.

Received: May 28, 2012

Accepted: June 27, 2012 